Ivana Simeunović ${ }^{1}$

Mladenka Balaban ${ }^{2}$

Duško Bodroža ${ }^{3}$
JEL: C02, C11, G22

DOI: 10.5937/industrija46-15164

UDC: 368.212(497.11)

368.021 .26

Original Scientific Paper

\title{
Pricing automobile insurance using mixed Poisson distributions ${ }^{4}$
}

\author{
Article history: \\ Received: 28 September 2017 \\ Sent for revision: 23 October 2017 \\ Received in revised form: 19 February 2018 \\ Accepted: 19 February 2018 \\ Available online: 20 March 2018
}

\begin{abstract}
Automobile insurance, particularly motor third liability insurance covers dominant share in the portfolio of non-life insurance in almost all countries of the world. The aim of this paper is to analyze the process of determining premium rates in automobile liability insurance using the bonusmalus system as one of the key instruments to increase traffic safety. The paper presents a brief analysis of the automobile liability insurance market in Serbia, with special reference to the bonus-malus system introduced in practice. Using a sample from the year 2015 provided by one of the biggest Serbian automobile liability insurer it has been proved that the mixed Poisson distibutions are appropriate choice in the process of modeling of the afore mentioned tariff system. The main result of the study is the construction of bonus - malus system based on mixed Poisson models, where expected value principle is used to determine the net premium. According to the analysis, it has been concluded that during the creation of a bonus-malus system in practice it is important to use certain mathematical and statistical models, as well as that the existing tariff system of automobile liability insurance in Serbia can be improved by introducing additional assumptions.
\end{abstract}

Keywords: automobile insurance, mixed Poisson distributions, determining premium, bonus-malus system, expected value principle.

\footnotetext{
${ }^{1}$ Belgrade Banking Academy, Faculty for banking, insurance and finance

2 Belgrade Banking Academy, Faculty for banking, insurance and finance

${ }^{3}$ Institute of Economic Sciences, dusko.bodroza@ien.bg.ac.rs

4 This paper is a part of research projects numbers 47009 and 179015 , financed by the Ministry of Science and Technological Development of the Republic of Serbia.
} 


\title{
Izračunavanje premije u osiguranju motornih vozila pomoću složenih Paoasonovih distribucija
}

\begin{abstract}
Apstrakt: Osiguranje motornih vozila, posebno osiguranje od autoodgovornosti zauzima dominatno učešće u portfelju neživotnih osiguranja u gotovo svim zemljama sveta. Cilj ovoga rada je analiza postupaka utvrđivanja premijskih stopa u osiguranju od autoodgovornosti korišćenjem bonus-malus sistema, kao jednog od ključnih instrumenata za povećanje bezbednosti saobraćaja. U radu je data kraća analiza tržišta osiguranja autoodgovornosti u Srbiji, sa posebnim osvrtom na primenu bonus-malusa $u$ praksi. Koristeći uzorak iz 2015. godine jednog od najvećih srpskih osiguravača autoodgovornosti dokazano je da su složene Poasonove distribucije adekvatan izbor u procesu modeliranja pomenutog tarifnog sistema. Osnovni rezultat istraživanja predstavlja konstriusani bonus-malus sistem baziran na složenim Poasonovim modelima, pri čemu je za određivanje premije korišćen princip očekivane vrijednosti. Iz sprovedene analize je zaključeno da je prilikom formiranja bonus-malus sistema u praksi značajno koristiti pojedine matematičko-statističke modele, kao i da je postojeći tarifni sistem autoodgovornosti u Srbiji moguće unaprediti uvođenjem dodatnih pretpostavki.
\end{abstract}

Ključne reči: osiguranje motornih vozila, složene Poasonove distribucije, utvrđivanje premije, bonus-malus sistem, princip očekivane vrednosti

\section{Introduction}

When creating premium rates in automobile liability insurance, the insurers take into account some a priori characteristics of the insured (gender, marital status, place of residence, etc) as well as motor vehicles (the type and purpose of the car, mileage, etc). In this way, the insured are classified into homogeneous risk classes according to certain characteristics that can be analyzed in advance. However, for the occurrence of the insured event, apart from a priori characteristics of the insured and the vehicle, the other hidden characteristics of the insured which cannot be analized in advance have impact. These characteristics, known as a posteriori driver's characteristics (emotional status, impulsiveness, speed in detection of traffic sign posts, etc.) are considered to manifest its influence in the occurrence of traffic accidents, in other words, the impact of the described characteristics of the insured can be determined by analyzing the number of reported claims. In that way, using information on the number of the reported claims of the insured, a priori rating is improved and premium rates are established which reflect the individual experience of the insured (Simeunović, 2008). 
The described tariff system based on the analysis of past experience of the insured is known as the bonus-malus system (merit rating, no claim discount). Such systems can be seen as commercial simplifications of credibility mechanisms (Pitrebois et. al., 2006). The introduction and implementation of a bonus-malus system in the formation of tariffs in motor vehicle insurance not only provides equivalence between the number of reported claims of the insured with their future premium, but it represents on of the key factors contributing to the improvement of traffic safety. The fact that they will pay increased premiums due to reported claim produces an incentive for the insured to drive more carefully, eliminating the inefficiencies associated with moral hazard (Bressand, 1993, Winter, 2000). In that way, one of the functions of the bonus-malus is fulfilled, while the other function of this method of experience-related premium determination is referred to the problem of adverse selection where nothing counts but the frequency of reported accidents (Henriet and Rochet, 1986). Application of bonus-malus is a response to the situation described by penalizing the more numerous claims of those with more dangerous driving patterns. Using the bonus-malus system is justified by the need to satisfy the principle of fairness in the collection of premiums, which means that the insured has to pay the premium corresponding to their level of risk (Lemaire 1995, Dionne and Vanasse, 1989).

It is interesting to mention a different approach to the method of bonus-malus which economists have compared to mathematicians. In economic literature, the introduction of bonus, that is malus is a means of neutralizing the effects of moral hazard. On the other hand, the greater part of the actuarial literature written by mathematicians reports that the main objective achieved by application of bonus-malus is better assessment of individual risk, which means that every individual in the long run will pay a premium that fits their claim frequency (Pitrebois at. all, 2006).

The introduction of bonus-malus practically involves the following steps: after determining the base premium, the rules for a transition from one level to another is determined, as well as the amount of discount that individual insured will take. Then, the insured are classified simply based on the number of claims reported over the past year into classes of discount, i.e. move up or down according to the established transition rules. The amount of the premium that will be paid is determined by multiplying the base premium by the percentage that is assigned to the amount of discount which the insured takes. In such a way all the policies that were previously in the same risk class are now classified into levels of discount or additional payments by using the bonus-malus system. In that way, the tariff system based on a priori risk classification is improved (Doerpinghaus at. all, 2003). 
Bonus-malus system was first applied in 1910 by British and Scandinavian insurers (Meyer, 2002). Then this system of tariffs was introduced in many other countries, where until the very end of the twentieth century there was a unique set of rules regarding application of bonus-malus in almost all European countries (Kafkova, 2015). Only when in 1994 a decree was adopted allowing the introduction of their own rules of application of bonusmalus, the previously used system of uniform tariffs was abolished. The mandatory system is still operating in France and Luxembourg (Silva at. all, 2005).

One of the reasons that justifies the existence of the afore mentioned tariff system in auto liability insurance is market-oriented business and extremely strong competition that forces insurers to establish rates that will more realistically reflect reality (David, 2015). That means that when determining premiums even the smallest details will be taken into account, and that great number of factors will be included in the analysis. Thus, for example in Germany, women would pay lower premiums for auto liability as more careful drivers and all experienced and responsible drivers who do not cause accidents will be granted excellent discounts on the base price of insurance. The most important factors for determining premium rates in auto liability insurance in California are as follows: length of driving experience, the number of kilometers traveled during the year, and of course, the experience of previous claims. In many countries, an important factor in the above sense is the place of residence of the insured, their age, and type of vehicle.

The next chapter brings about a brief analysis of automobile liability insurance market in Serbia. Then methodology used in the article is presented, after which modeling of claim frequency was conducted in the analyzed sample. The system of optimal bonus-malus follows, performed on the model of selected distribution of claim counts where the principle of the expected value is used in constructing the premium. The final section brings conclusion.

\section{Automobile liability insurance market in Serbia}

Motor vehicles today represent one of the biggest dangers that threaten humankind. The car is often cited as the main source of economic losses (Gomez at. all, 2002). Despite the growing advancement of science and technology in increasing traffic safety the number of accidents is growing. Their harmful effects have become immeasurable, both in material terms and in a vast number of casualties. Compulsory automobile liability insurance can be seen as a legal requirement for the use of motor vehicles. In fact, this form of insurance reflects the rights of all participants in traffic to expect traffic safety, and the protection of their lives, health and property. In this way, the 
proper implementation of automobile liability insurance is one of the key assumptions in the process of regulating and improving traffic safety. Therefore, the process of creating an adequate tariff system is of vital interest to the solution of this problem and one of the most effective methods from this point of view, is, indeed, the proper application of the bonus-malus system.

Automobile liability insurance as one of the forms of motor vehicle insurance takes up the largest share of total non-life insurance premium in almost all countries of the world. In some countries it is the most common form of insurance in total insurance premium, as it is in Serbia (Simeunović at. all, 2012).

If we analyze the period of the last five years, it can be found that the Serbian market structure has not changed. Automobile insurance leads in total sales, with $33.3 \%$ of the market in 2010 and $35.8 \%$ in 2015 , and at the same time, the share of motor third party liability insurance (MTPL) occupies nearly a third of the total portfolio insurance in the observed period (Table 1).

Table 1: Structure of total portfolio insurance in Serbia (\%), 2010-2015

\begin{tabular}{|c|c|c|c|c|c|c|}
\hline & 2010 & 2011 & 2012 & 2013 & 2014 & 2015 \\
\hline Property & 22.1 & 22 & 22.2 & 21.6 & 20.04 & 18.2 \\
\hline MTPL & $\mathbf{3 3 . 3}$ & $\mathbf{3 2 . 6}$ & $\mathbf{3 1 . 5}$ & $\mathbf{3 0 . 6}$ & $\mathbf{3 2 . 7}$ & $\mathbf{3 5 . 8}$ \\
\hline Casco & 13.5 & 12.5 & 11.3 & 10 & 8.7 & 7.7 \\
\hline Accident & 8.5 & 8.6 & 6.3 & 5.5 & 5.8 & 5.3 \\
\hline Other P\&C & 6.1 & 6.9 & 9.4 & 10.3 & 9.66 & 9.1 \\
\hline Total P\&C & 83.5 & 82.6 & 80.7 & 78 & 76.9 & 76.1 \\
\hline Total Life & 16.5 & 17.4 & 19.3 & 22 & 23.1 & 23.9 \\
\hline Total & 100 & 100 & 100 & 100 & 100 & 100 \\
\hline
\end{tabular}

Source: https://www.nbs.rs/internet/english/60/60_6/index.html

In comparison with the previous year the automobile liability insurance has grown by $9.48 \%$, with total gross premium in the amount of 28,816 million RSD. Distribution (table 2) of frequencies of auto liability insurance policies follows as well as the automobile liability total premium by the company for the year 2015.

Continued growth and significance of motor vehicles insurance, especially auto liability insurance increasingly emphasizes competition, which greatly influence the amount of insurance premium. The rating system used for third party liability insurance in Serbia is essentially based on horsepower plus a bonus - malus system introduced in 2011. Application of the experience based premium determination is conducted by allowing a discount of $5 \%$ for the first year with no claim reported. Discount of $10 \%$ and $15 \%$ is granted to the drivers who in two and three years do not record claim, respectively. This is also the maximum discount that can be achieved. When it comes to 
increasing the base premium to drivers who cause accidents, they will pay premium increased by $50 \%$ if they record one claim. If they have two claims the premium increases by $100 \%$ while in case of three claims during one year, the policy holders would pay premium increased by $150 \%$. When malus is applied it is important to note that the reported claims are associated with the vehicle, not the insured, because of which the car owner has to pay the increase premium even if he did not conduct his car.

Table 2: The share of automobile liability insurance policies and total premium (GWP) by companies in 2015

\begin{tabular}{|c|c|c|}
\hline Company & GWP 2015 (000 RSD) & Share (\%) $\mathbf{2 0 1 5}$ \\
\hline Dunav & $9,811,530$ & 33.82 \\
\hline Generali & $6,366,433$ & 21.95 \\
\hline DDOR & $3,211,377$ & 11.07 \\
\hline Milenijum & $2,269,399$ & 7.82 \\
\hline AMS & $2,152,083$ & 7.42 \\
\hline Triglav & $2,008,117$ & 6.92 \\
\hline Sava Neživotno & $1,271,269$ & 4.38 \\
\hline Uniqa Neživotno & $1,078,090$ & 3.72 \\
\hline Wiener & 529,518 & 1.83 \\
\hline AXA Neživotno & 307,420 & 1.06 \\
\hline Globos & 2,075 & 0.01 \\
\hline Total & $\mathbf{2 9 , 0 0 7 , 3 8 0}$ & $\mathbf{1 0 0}$ \\
\hline
\end{tabular}

Source: https://www.nbs.rs/internet/english/60/60_6/index.html

The next chapter brings about the analysis of a selected sample of Serbian automobile liability insurer. The corresponding bonus-malus system would be constructed then.

\section{Metodology}

This paper analyzes a selected sample containing 61,796 units in terms of the number of reported claims by the insured. It was determined which model can be used for modeling of the observed claims, and then by application of bonus-malus the tariff system would be constructed to ensure equivalence between the frequency of claims of some policyholders and their future premiums.

In order to construct described bonus-malus system, the analysis of the selected sample has to be made first from the point of view of the frequency of reported claims by the insured (Stephens at. all, 2004). By modeling claim frequencies different distributions would be analyzed and those which empirical data best adjusts would be chosen. Our starting hypothesis will be that the analyzed data can be modeled using mixed Poisson distributions. 
Let us choose the arbitrary policy holder from the observed sample. Denote with $N_{t}$ the number of reported claims of the insured at some period $t$. Further let us assume that the random variable can be approximated by Poisson distribution whose unknown parameter equals $\Theta$ where $\Theta$ is a random effect accounting for the heterogeneity present in the portfolio. The conditional probability mass function of $N_{t}$ is given by (Bühlmann, 1970):

$$
P\left[N_{t}=k \mid \Theta=\theta\right]=e^{-\theta} \frac{\theta^{k}}{k !}
$$

Given the fact that within the portfolio of the automobile liability insurance policyholder heterogeneity is present, and that each policyholder shows a different propensity to cause traffic accidents, the mentioned heterogeneity in the portfolio is described by a structure function $u$ (density function of a random variable $\Theta$ ).

$$
P\left[N_{t}=k\right]=\int_{0}^{\infty} e^{-\theta} \frac{\theta^{k}}{k !} u(\theta) d \theta
$$

Due to the presence of heterogeneity between some policyholders, we will prove that the sample data cannot be modeled by Poisson distribution for which we assume below that the data can be described by using mixed Poisson distribution, such as Poisson-Gamma and Poisson-Inverse Gaussian distribution. To estimate unknown parameters of the assumed distribution the maximum likelihood method will be used or the method of moments, while $\chi^{2}$ test is used for the adjustment of the data to the assumed distribution.

First, let us assume that the parameter $\Theta$ of Poisson distribution follows Gamma distribution - $\Theta: \Gamma(a, \tau)$ whose density function is given by:

$$
u(\theta)=\frac{\tau^{a} e^{-\tau \theta} \theta^{a-1}}{\Gamma(a)} \quad a, \tau>0
$$

The resulting distribution for modelling claim frequencies in the portfolio known as a Poisson-Gamma (negative binomial) distribution then have the following form (Lemaire, 1995): 


$$
p_{k}=\left(\begin{array}{c}
k+a-1 \\
k
\end{array}\right)\left(\frac{\tau}{1+\tau}\right)^{a}\left(\frac{1}{1+\tau}\right)^{k}=\left(\begin{array}{c}
k+a-1 \\
k
\end{array}\right) p^{a} q^{k}
$$

The first and the second moment of the described distribution are equal to:

$$
E(X)=\frac{a}{\tau}, \quad \sigma^{2}=\frac{a}{\tau}\left(1+\frac{1}{\tau}\right)
$$

For the calculation of negative binomial probabilities the following recursion will be used:

$$
p_{k+1}=p_{k} \cdot \frac{k+\hat{a}}{(k+1) \cdot(1+\hat{\tau})}
$$

where:

$$
p_{0}=\left(\frac{\tau}{1+\tau}\right)^{a}
$$

In the following, we use the assumption that the unknown parameter $\Theta$ of Poisson distribution follows inverse Gaussian distribution - $\Theta: I G(g, h)$ whose density function is given by:

$$
u(\theta)=\frac{g}{\sqrt{2 \pi h \theta^{3}}} e^{\left(-\frac{1}{2 h \theta}(\theta-g)^{2}\right)}, \quad g, h>0
$$

The resulting distribution is known as Poisson-Inverse Gaussian and its mean and variance are equal to:

$$
\mu=g, \quad \sigma^{2}=g(1+h)
$$

Finally, by putting $E(\Theta)=1$ we get the expression for the resulting PoissonInverse Gaussian distribution of the frequency of claims in the portfolio:

$$
p_{k}=\int_{0}^{\infty} e^{-\theta} \frac{\theta^{k}}{k !} \frac{1}{\sqrt{2 \pi h \theta^{3}}} e^{\left(-\frac{1}{2 h \theta}(\theta-h)^{2}\right)} d \theta k=0,1,2, \ldots,
$$

In the application of the described mixed Poisson model for calculation of the probabilities, we used the following expression: 


$$
p_{k}=\frac{h(k-1)(2 k-3) p_{k-1}+g^{2} p_{k-2}}{(1+2 h) k(k-1)}
$$

To create the tariff system which would reflect the individual experience of the insured, we used Bayesian credibility premium model (Bowers at. all, 1986).

Previously, we assumed that the risk of each insured makes one realization $\theta>0$ of the random variable $\Theta$. Let us consider portfolio of policyholders in a given period of time $t$, where in the course of the $j$-year, each policy holder reported $k_{j}$ claims. Thus, the experience of the individual policyholder during the observed period of time will be presented by vector $\left(k_{1}, k_{2}, \ldots . . k_{t}\right)$. Realizations of the random variable $K_{j}$ that represent the individual experience of the insured during the observed period are assumed to be independent. After we chose the resulting probability function for the number of claims, according to the data regarding the number of reported claims by the policyholders in the sample, we would form the function which would be a measure of risk taken in insurance for the following year $\theta_{t+1}=\theta_{t+1}\left(k_{1}, k_{2}, \ldots . k_{t}\right), t=0,1,2 \ldots$.

By application of Bayesian theorem and known experience regarding claims given by the vector $\left(k_{1}, k_{2}, \ldots . . k_{t}\right)$ the posterior structure function is equal to:

$$
u\left(\theta \mid k_{1}, k_{2}, \ldots . k_{t}\right)=\frac{P\left(k_{1}, k_{2}, \ldots . k_{t} \mid \theta\right) u(\theta)}{P^{\prime}\left(k_{1}, k_{2}, \ldots k_{t}\right)}
$$

where:

$$
P^{\prime}\left(k_{1}, k_{2}, \ldots k_{t}\right)=\int_{0}^{\infty} P\left(k_{1}, k_{2}, \ldots . k_{t} \mid \theta\right) u(\theta) d \theta
$$

denotes the expression which represents distribution of the number of claims during the analyzed years of observation $t$ (Lemaire, 1995).

If $L_{t+1}\left(\theta_{t+1}, \theta\right)$ denotes the loss function and $R_{t+1}=R_{t+1}\left(\theta_{t+1}, \theta\right)$ denotes the risk function of actuary, it turns that: 


$$
R_{t+1}\left(\theta_{t+1}, \theta\right)=E\left[L_{t+1}\left(\theta_{t+1}, \theta\right)\right]=\sum L_{t+1}\left(\theta_{t+1}, \theta\right) P\left(k_{1}, k_{2}, \ldots k_{t}\right)
$$

Further we would minimise the following expression for each year $t$ and each vector $\left(k_{1}, k_{2}, \ldots . . k_{t}\right)$ :

$$
\int_{0}^{\infty} L_{t+1}\left(\theta_{t+1}, \theta\right) u\left(\theta \mid k_{1}, k_{2}, \ldots . . k_{t}\right) d \theta
$$

Finally, taking that the loss function is a quadratic form, it is necessary to find a minimum of the following function:

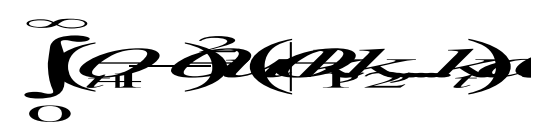

where the following expression represents the Bayesian credibility premium:

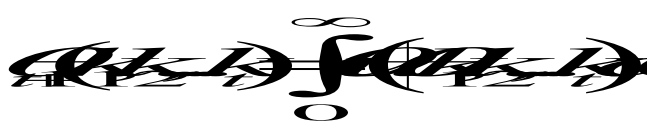

For the construction of the described system of tariffs known as the optimal bonus-malus system, we used the expected value premium calculation principle as one of the simplest principles which can be applied in this regard. Applying this principle, the amount of the premium which the insured would pay is obtained when security loading is added to calculated net premium which is proportional to the amount of net premium. Thus, the insured whose previous experience of claims is represented by vector $\left(k_{1}, k_{2}, \ldots . . k_{t}\right)$ would pay a premium in the following amount (Nadarajah, at. all, 2006):

$$
P\left(k_{1}, k_{2}, \ldots k_{t}\right)=(1+\alpha) \theta_{t+1}\left(k_{1}, k_{2}, \ldots k_{t}\right)
$$

Below we will draw the expression which is used for calculation of the posterior premium in the system of the described bonus-malus based on mixed Poisson models.

\subsection{Poisson-Gamma model}

If $k=\sum_{i=1}^{t} k_{i}$ denotes the total number of reported claims by the individual policyholder during $t$ years, then the estimate of the mean claim frequency 
for the group of the insured whose experience on previous claims is represented by vector $\left(k_{1}, k_{2}, \ldots . . k_{t}\right)$ :

$$
\theta_{t+1}\left(k_{1}, k_{2}, \ldots k_{t}\right)=\frac{a+k}{\tau+t}=\frac{a^{\prime}}{\tau^{\prime}}
$$

According to the principle of the expected value the net premium is equal to:

$$
P\left(k_{1}, k_{2}, \ldots k_{t}\right)=c(1+\alpha) \theta_{t+1}\left(k_{1}, k_{2}, \ldots k_{t}\right)=c(1+\alpha) \frac{a^{\prime}}{\tau^{\prime}}
$$

Having in mind that the company's expected income per policy holder is:

$$
\sum \theta_{t+1}\left(k_{1}, k_{2}, \ldots k_{t}\right) \bar{P}\left(k_{1}, k_{2}, \ldots k_{t}\right)=\frac{a}{\tau}
$$

and assuming that the base premium amount is 100, the expression for calculation of a posteriori net premium is given in the system of optimal bonus-malus derived from Poisson-Gamma model:

$$
P^{\prime}\left(k_{1}, k_{2}, \ldots k_{t}\right)=100 \frac{\frac{a+k}{\tau+t}}{\frac{a}{\tau}}=100 \frac{\tau(a+k)}{a(t+\tau)}
$$

\subsection{Poisson- Inverse Gaussian model}

If the experience on previous claims of the observed group of policyholders is represented by vector $\left(k_{1}, k_{2}, \ldots . . k_{t}\right)$, then the structure function for this model (Besson and Partrat, 1992) is:

$$
u\left(\theta \mid k_{1}, k_{2}, \ldots k_{t}\right)=\frac{P\left(k_{1}, k_{2}, \ldots k_{t} \mid \theta\right) u(\theta)}{\int_{0}^{\infty} P\left(k_{1}, k_{2}, \ldots k_{t} \mid \theta\right) u(\theta) d \theta}
$$

After simplification of this expression (Lemaire, 1995), it becomes: 


$$
u\left(\theta \mid k_{1}, k_{2}, \ldots k_{t}\right)=\theta^{a} e^{-\frac{\theta}{b}} e^{-\frac{c}{\theta}}
$$

where by putting that $a=k-\frac{3}{2}, b=\frac{2 h}{2 t h+1}, c=\frac{g^{2}}{2 h}$ and introducing $a=v-1, b=2 \beta$ and $c=\frac{\mu^{2}}{2 \beta}$, it is obtained that the density function of generalized inverse Gaussian distribution is:

$$
f(\theta)=\frac{\theta^{v-1} e^{-\frac{\theta}{2 \beta}} e^{-\frac{\mu^{2}}{2 \beta}}}{2 \mu^{v} K_{v}\left(\frac{\mu}{\beta}\right)}
$$

As the generalized inverse Gaussian distribution is conjugate family for the Poisson, it reduces to inverse Gaussian when $v=\frac{1}{2}$. If we further introduce the equation $Q_{k}(u)=\frac{K_{k+\frac{1}{2}}(u)}{K_{k-\frac{1}{2}}(u)}$, the posterior premium is calculated using the expected value principle and the described model becomes (Lemaire, 1995):

$$
P_{t+1}\left(k_{1}, k_{2}, \ldots k_{t}\right)=(1+\alpha) \mu Q_{k}\left(\frac{\mu}{\beta}\right)
$$

In the application of the stated formula, in the following chapter recursion is used $Q_{k}(u)=\frac{2 k-1}{u}+\frac{1}{Q_{k-1}(u)}$, as well as one of the important features of $K_{v}(u)$, and that is that $Q_{0}(u)=1$.

\section{Empirical research and discussion}

The aim of this chapter is to design rating plan in accordance with the information on previous experience of the policy holders, taking into account the data on the number of reported claims of the policy holders in the previous year. 
As it was stated before, we will first choose distribution for the selected sample which fits the best the analized data. The following table shows the frequency distribution of the number of reported claims of the insured during the year 2015.

Table 3: Frequency distribution of the insured according to the number of reported claims

\begin{tabular}{|c|c|}
\hline Number of claims & Frequency of the insured \\
\hline 0 & 55,215 \\
\hline 1 & 6,014 \\
\hline 2 & 518 \\
\hline 3 & 46 \\
\hline 4 & 3 \\
\hline 25 & 0 \\
\hline$\sum$ & 61,796 \\
\hline
\end{tabular}

Source: Author's calculation

In order to determine the expected (fitted) distribution of number of claims we first estimated unknown parameters of the assumed distributions using the moment method. Then, probabilities are calculated for each model which we apply multiplied by the sample size, thus getting the expected frequences. The mean and the variance of the sample are equal to:

$\bar{x}=\frac{1}{n} \cdot \sum_{i=1}^{n} X_{i} \cdot f_{i}=0.116512 \quad s^{2}=\frac{1}{n-1} \cdot \sum_{i=1}^{k} f_{i} \cdot\left(X_{i}-\bar{x}\right)^{2}=0.124753$

Table 4: Expected claim frequences according to the selected distribution

\begin{tabular}{|c|c|c|c|c|}
\hline \multirow{2}{*}{$\begin{array}{c}\text { Number } \\
\text { of } \\
\text { claims }\end{array}$} & \multirow{2}{*}{$\begin{array}{c}\text { Observed } \\
\text { frequencies }\end{array}$} & $\begin{array}{c}\text { Poisson } \\
\text { model }\end{array}$ & $\begin{array}{c}\text { Poisson-Gamma } \\
\text { model }\end{array}$ & $\begin{array}{c}\text { Poisson-Inverse } \\
\text { Gaussian model }\end{array}$ \\
\hline $\mathbf{0}$ & 55,215 & $54,999,62$ & $55,216,51$ & $55,211,90$ \\
\hline $\mathbf{1}$ & 6,014 & $6,408,14$ & $6,008,45$ & $6,021,10$ \\
\hline $\mathbf{2}$ & 518 & 373.31 & 525.35 & 514.85 \\
\hline $\mathbf{3}$ & 46 & 14.50 & 42.19 & 43.84 \\
\hline $\mathbf{4}$ & 3 & 0.42 & 3.24 & 3.91 \\
\hline $\mathbf{2}$ & 0 & 0.01 & 0.24 & 0.36 \\
\hline
\end{tabular}

Source: Author's calculations

Table 5 contains values of the estimated parameters of the assumed distributions, as well as realized values of $\chi^{2}$ the statistic test. 
Simeunović I. et. al.: Pricing automobile insurance using mixed Poisson distributions

Table 5: Realized $\chi^{2}$ statistic test values and estimated parameters

\begin{tabular}{|c|c|c|c|}
\hline Distribution & Poisson & Poisson-Gamma & Poisson-Inverse Gaussian \\
\hline Parameters & $\hat{\theta}=0.116512$ & $\hat{a}=1.647350$ & $\hat{g}=0.116512$ \\
\hline$\chi^{2}=\frac{\left(f_{i}-f_{i}^{\prime}\right)^{2}}{f_{i}^{\prime}}$ & 165.35 & 0.711 & $\hat{\boldsymbol{\tau}}=0.070727$ \\
\hline
\end{tabular}

Source: Author's calculations

From the inequality $\chi^{2}=165.35>7.815=\chi^{2} 3 ; 0.95$ it can be concluded that the observed distribution cannot be modeled by the Poisson distribution, while the hypothesis of adjusting of claim frequency mixed Poisson models (Poisson-Gamma and Poisson-Inverse Gaussian) retains with statistical significance at the $5 \%$, since the following can be applied:

$$
\chi^{2}=0.711<7.815=\chi^{2} 3 ; 0.95 \text { as well as } \chi^{2}=0.709<7.815=\chi_{3 ; 0.95}^{2}
$$

Once we have proven adjustment of the frequency of reported claims of the policyholders in the selected sample by some compound Poisson distributions, further we along with previously described model, the optimal bonus-malus premium system has been drawn, which gives the amount of the premium that should be paid by the policy holder who during the period of $t$ years reports $k$ claims.

Table 6: Optimal Bonus-Malus - Poisson-Gamma model

\begin{tabular}{|c|c|c|c|c|c|c|c|}
\hline $\begin{array}{c}\text { No. of } \\
\text { years } \\
\text { without } \\
\text { claim }\end{array}$ & \multicolumn{7}{|c|}{$\begin{array}{c}\text { Number of reported claims by the policyholder } \\
\mathbf{k}\end{array}$} \\
\hline $\mathbf{t}$ & $\mathbf{0}$ & $\mathbf{1}$ & $\mathbf{2}$ & $\mathbf{3}$ & $\mathbf{4}$ & $\mathbf{5}$ & $\mathbf{6}$ \\
\hline $\mathbf{0}$ & 100 & & & & & & \\
\hline $\mathbf{1}$ & 93.39 & 150.09 & 206.79 & 263.48 & 320.18 & 376.88 & 433.57 \\
\hline $\mathbf{2}$ & 87.61 & 140.79 & 193.94 & 247.16 & 300.34 & 353.52 & 406.71 \\
\hline $\mathbf{3}$ & 82.49 & 132.57 & 182.66 & 232.74 & 282.82 & 332.90 & 382.98 \\
\hline $\mathbf{4}$ & 77.95 & 125.27 & 172.58 & 219.90 & 267.22 & 314.54 & 361.86 \\
\hline $\mathbf{5}$ & 73.87 & 118.72 & 163.57 & 208.41 & 235.26 & 298.11 & 342.95 \\
\hline $\mathbf{6}$ & 70.21 & 112.83 & 155.44 & 198.06 & 240.68 & 283.30 & 325.92 \\
\hline $\mathbf{7}$ & 66.88 & 107.49 & 148.09 & 188.69 & 229.30 & 269.90 & 310.51 \\
\hline
\end{tabular}

Source: Author's calculations 
Simeunović I. et. al.: Pricing automobile insurance using mixed Poisson distributions

Table 7: Optimal Bonus-Malus - Poisson-Inverse Gaussian model

\begin{tabular}{|c|c|c|c|c|c|c|c|}
\hline $\begin{array}{c}\text { No. of years } \\
\text { without claim }\end{array}$ & \multicolumn{7}{|c|}{ Number of reported claims by the policyholderk } \\
\hline $\mathbf{t}$ & $\mathbf{0}$ & $\mathbf{1}$ & $\mathbf{2}$ & $\mathbf{3}$ & $\mathbf{4}$ & $\mathbf{5}$ & $\mathbf{6}$ \\
\hline $\mathbf{0}$ & 100 & & & & & & \\
\hline $\mathbf{1}$ & 94.26 & 151.18 & 223.41 & 303.05 & 408.47 & 493.10 & 544.64 \\
\hline $\mathbf{2}$ & 88.25 & 142.27 & 205.75 & 275.17 & 338.17 & 471.23 & 497.82 \\
\hline $\mathbf{3}$ & 85.64 & 131.98 & 192.03 & 259.76 & 328.27 & 375.47 & 471.42 \\
\hline $\mathbf{4}$ & 82.06 & 126.37 & 179.54 & 241.68 & 301.91 & 357.72 & 421.74 \\
\hline $\mathbf{5}$ & 78.50 & 119.58 & 169.44 & 224.96 & 284.46 & 326.41 & 394.22 \\
\hline $\mathbf{6}$ & 74.97 & 112.67 & 158.11 & 210.06 & 269.14 & 313.64 & 341.19 \\
\hline $\mathbf{7}$ & 70.21 & 107.40 & 151.27 & 200.38 & 247.31 & 299.87 & 329.76 \\
\hline
\end{tabular}

Source: Author's calculations

The main characteristics of the tariff system built on the basis of the described mixed Poisson distributions is that it is a system that is financially balanced ${ }^{5}$ which means that the amount of expected claims is equal to the amount of the total premium. To achieve this effect, the derived bonus-malus system proposes discounts (bonuses), which are very close to those used in practice, while on the other hand, certain maluses are stricter than those currently applied. Described stricter penalizing of the drivers who cause accidents is the result of the fact that it takes approximately eight years to eliminate the effects of the reported claim. Also, the described system of tariffs is drawn from the the analysis of considerably longer period without claim as it allows granting additional discount for each subsequent year with no reported claim. In contrast to a maximum discount of $15 \%$ after three years without the claim which has been implemented in practice, the described system of rewarding conscientious drivers can create an incentive to others to drive more carefully and thus pay lower premiums.

As the bonus-malus systems is in force throughout the world, except in Korea (Denuit at. all, 2007), the described system of tariffs penalize drivers based on information on the number of claims, without taking into account the cost of these claims, nor the distribution according to which these damages occure during the year.

\section{Conclusion}

This paper analyzes a selected sample of Serbian automobile liability insurer and the suggestion regarding tariffs is given, that is the optimal bonus-malus.

\footnotetext{
5 The financial stability of the bonus-malus system is a direct consequence of the property of conditional expectation: $E_{W}[W]=E_{V}\left[E_{W}[W \mid V]\right.$
} 
As we have seen, the proposed tariff system is based on information about the previous claims experience of the insured individuals, thus meeting the basic principle on which price of insurance is made, and that is the principle of fairness. Described bonus-malus makes it possible to improve the insurance rating and thus render risk classes more homogeneous.

Analysis of the sample in terms of frequency of the reported claims by the policyholder proves the hypothesis that in the modeling of claim counts mixed Poisson distributions can be used, in particular Poisson - Gamma and Poisson - Inverse Gaussian. Based on the properties of the selected distributions using the principle of expected value we derived the bonus-malus system whose main characteristics are described in the previous section. One of them is the fact that the proposed tariffs are derived using only data on the frequency of reported claims of the insured. Thus, one important factor is neglected in determining the tariff, and that is the amount of previously reported claims. Apart from the stated defect, the suggested system of tariffs could be improved by introducing additional a priori characteristics of the policyholders, as well as motor vehicle. Of particular importance may be some characteristics of the policyholders such as sex, length of driving experience, age, etc. The analysis of the described limitations of the established tariffs is the next step that the authors intend to implement. This could also be the critique of the existing tariffs in automobile liability insurance applied in the Serbian market. If the non-existence of the risk zones is taken into account, as well as recently introduced system of bonus-malus, one of the key findings of this article could be the fact that it is necessary to determine new long-term strategy in Serbia regarding development of automobile liability insurance which includes a complex differentiation of premium rates and their adjustment to individual risk. That ensures the sufficiency of the premiums collected as well as timely and adequate compensation of claims. One way to solve the problem described would be adequate cooperation with relevant authorities of the Ministry of Internal Affairs of the Republic of Serbia, which would be primarily reflected in the availability of certain information. Based on this information it would be possible to make numerous analyses such as determining the ratio of the number of claims and the number of vehicles, determine the average amount of claim for the vehicle (the ratio of the total amount of claims and the number of insured vehicles), claim structures (by type and amount), identification of characteristics of those who cause traffic accidents, the proportion of certain areas (risk zones) in the total number of traffic accidents, and so on (Simeunović, 2010).

The formation of tariffs in automobile liability insurance by applying mathematical and statistical models is one of the basic requirements of insurers in developed countries. Today, there is a variety of different models in use which can successfully quantify individual risk factors that are associated with both the insured and their main characteristics, as well as with 
the insured vehicle. The findings of the analysis in this paper, together with proposed bonus-malus system, may be useful guidelines, that is a solid starting point for the insurers in the creation of premium rates. At the same time, these and similar analyses of the tariff system in automobile liability may encourage consideration and implementation of various actuarial models which become increasingly important.

\section{References}

Besson, J.L., \& Partart, C. (1992). Trend et Systemes de Bonus-Malus. ASTIN Bulletin, 22, 11-31.

Bowers, N., Gerber, H., Hickman, J., Jones, D., \& Nesbit, C. (1986). Actuarial mathematics. Itasca: The society of actuaries.

Bressand, C. (1993). A' propos de la tarification de l'assurance automobile. Économie et Prévision, 108, 75-96.

Bühlmann, H. (1970). Mathematical methods in risk theory. New York: Springer.

David, M. (2015). Auto insurance premium calculation using generalized linear models, Procedia Economics and Finance, 20, Elsevier B.V, 147 - 156.

Denuit, M., Marechal, X., Pitrebois, S., \& Walhin, J.F. (2007). Actuarial modelling of claim counts, Risk classification, Credibility and Bonus-malus systems. John Wiley\&Sons, Inc..

Dionne, G., \& Ghali, O. (1992). The Bonus-Malus system in Tunisia: An empirical evaluation. The Journal of Risk and Insurance, 72(4), 609-633.

Dionne, G., \& Vanasse, C. (1989). A Generalization of Automobile Insurance Rating Models: the negative binomial distribution with a regression component. ASTIN Bulletin, 19(2), 199-212. doi:10.2143/AST.19.2.2014909

Doerpinghaus, P., Schmit, J., \& Yeh, J.J.H. (2003). Personal bias in automobile claims settlement. The Journal of Risk and Insurance, 70(2),

Gomez, E., Hernandez, A., Perez, J.M., \& Vazquez-Polo, F.J. (2002). Measuring sensitivity in a bonus-malus system. Insurance: Mathematics and Economics, 31(2002),

Henriet, D., \& Rochet, J.C. (1986). La logique des systemes Bonus-Malus en assurance automobile: Une approche theorique. Annales d'Economie et de Statistique, 1, 133-152.

Kafkova, S. (2015). A Comparison of Several Bonus Malus Systems, Procedia Economics and Finance, 26, Elsevier B.V, $188-193$.

Lemaire, J. (1995). Bonus-malus systems in automobile insurance. Boston: Kluwer Academic Publishers.

Meyer, U. (2002). Third party motor insurance in Europe. Bamberg: University of Bamberg.

Nadarajah, S., \& Kotz, S. (2006). Compound mixed Poisson distributions II. Scandinavian Actuarial Journal, 3, 163-181.

Pitrebois, S., Deniut, M., \& Jean-Francois, W. (2006). An actuarial analysis of the French bonus-malus system. Scandinavian Actuarial Journal, 5, 247-264.

Silva, J.M.A., \& Centeno, M.L. (2005). A Note on Bonus Scales. Journal of Risk Insurance, 72(4), 601-607. doi:10.1111/j.1539-6975.2005.00140.x 
Simeunović I. et. al.: Pricing automobile insurance using mixed Poisson distributions

Simeunović, I. (2008). Iskustveno određivanje premije - bonus sistem. Industrija, 36(1), 67-76. Ekonomski institut.

Simeunović, I. (2010). Statističko-aktuarske osnove i rešavanje problema u procesu utvrdivanja premije $u$ osiguranju od autoodgovornosti. Beograd: Univerzitet Union. doktorska disertacija.

Simeunović, I., Domazet, I., \& Balaban, M. (2012). Bonus-malus sistem kao sastavni deo tarife autoodgovornosti. ANALI Ekonomskog fakulteta u Subotici,, 28, 313325.

Stephens, D.A., Crowder, M.J., \& Dellaportas, P. (2004). Quantification of automobile insurance liability: A Bayesian failure time approach. Insurance: Mathematics and Economics, 34,

Winter, R.A. (2000). Optimal Insurance Under Moral Hazard. In Handbook of Insurance. (pp. 155-183). Boston: Kluwer Academic Publishers. 